\title{
Introducing Manufacturing engineering with Kentucky Governors Scholar Program
}

\section{Dr. Jaby Mohammed, Petroleum Institute}

Dr. Jaby Mohammed is a faculty at The Petroleum Institute, Abu Dhabi, UAE. He received his Ph.D. in Industrial engineering from University of Louisville (2006), Masters in Industrial engineering from University of Louisville (2003), and also a master's in Business Administration from Indira Gandhi National Open University (2001). His research interest includes advanced manufacturing, design methodologies, six sigma, lean manufacturing, and enterprise resource planning. He previously taught at Indiana Purdue Fort Wayne in Indiana and at Morehead State University in Kentucky. He is a member of IIE, SME, ASQ, ASEE, and Informs. 


\title{
Introducing Manufacturing engineering with Kentucky Governors Scholar Program
}

\begin{abstract}
Industry and community engagement in engineering programs are becoming more common compared to the past. There is much more than the technical skills that are needed for engineering students to succeed in the 21st century. The Kentucky Governor's Scholars Program (GSP) strives to enhance Kentucky's next generation of civic and economic leaders and to create models of educational excellence for teachers and students. Established in 1983, the program provides academic and personal growth through a balance of a strong liberal arts program with a full co-curricular and residential life experience. In this paper authors will discuss on the engineering focus group at Kentucky's Governors Scholars Program and discuss about the manufacturing curriculum and industry engagement of the program. More than half of the program activities are through manufacturing industry engagement. The program showcases the potential to engage students in a real life application of Science, Technology, Engineering, and Mathematics (STEM) coalition models that they learn in the classroom, to introduce engineering to students who may not have initially been drawn to engineering. The industry engagement also serves as the medium to reinforce models of learning which will be useful for students when they decide on the career choice and professional workforce. Also in this paper authors would show how they are able to incorporate social and community issues where the students use class room knowledge and hands on experience to get to solutions, which may be difficult to show in a classroom setting for a technical subject.

The paper will also address how the engineering focus group at the Kentucky Governors Scholars programs with the manufacturing industry engagement empowers students to:

- Apply knowledge of mathematics, science, and engineering

- Ability to analyze and interpret data

- Ability to design system, and process to meet the desired needs with realistic constraints such economic, environmental, social, health and safety, and sustainability

- Ability to work in multidisciplinary teams

- Knowledge of the current issues

- Understanding professional and ethical responsibility
\end{abstract}

The Governors program is a five week residential program and the engineering focus area directly hits on various ABET outcomes, that most of the engineering curriculum is designed upon.

\section{Introduction}

The Governor's Scholars Program is a summer residential program for outstanding high school students in Kentucky who are rising seniors. The Program originated in 1983 as a result of Kentucky leaders' concern that the state's "best and brightest" were leaving the Commonwealth to pursue educational and career opportunities elsewhere without fully understanding the 
potential of their talents at home. Students who are selected attend the Program without charge. In the spirit of partnership, the Office of the Governor, the Kentucky State Legislature, and private enterprise come together to provide the financial support for the Program ${ }^{1}$.

The Program's mission is to enhance Kentucky's next generation of civic and economic leaders. The first class numbered 230 and was housed on one college campus. Since then, the Program has enjoyed excellent support and grown to over 1,000 students on three campuses.

There are three campuses for the governor's scholars programs and they are housed in the various Universities (Public and Private Universities) in Kentucky.

There are many engineering schools in the nation that conduct summer school for students so that it provides a pre-college experience that challenges and promotes STEM (Science, Technology, Engineering, and Mathematics) experience. Many schools use this as a recruitment tool to get the students from all around to experience the taste of campus life, experience hands on projects, and with related experience. Valencia Community College offers a more specialized Associate degree in pre-engineering to increase recruitment of local high school students who are interested toward engineering education. The program assisted high school students to bridge the gap between high school and a four-year institution to motivate students to continue their engineering education with support from government and local industries ${ }^{2}$. The Bagley College of Engineering at Mississippi State University admitted students expressing interest in engineering who do not meet the criteria as undecided majors with a pre-engineering concentration where they work towards meeting the requirement for admission ${ }^{3}$. The difference with the Kentucky Governors Scholar Program to other Engineering summer school program is that first of all it is not a recruitment tool and secondly it is more than just an engineering experience.

\section{Core curriculum}

Applicants can choose from twenty possible disciplines. The disciplines range from astronomy to architecture and from engineering to environmental issues to name some. All the twenty disciplines have similar curriculum structure but different approaches in delivering the same. The core curriculum for the governor's scholars programs is threefold:

- Focus Area: a "major" subject of study, assigned according to scholar preference as indicated on the application.

- General Studies: an area of study assigned by staff to challenge the scholars. Courses frequently include service-learning components in the community.

- Seminar: a discussion-based small group session. Emphasis is placed on respectful debate and discussion. Scholars are encouraged to ask probing questions.

Faculty and staff also invite a variety of speakers and performers from a range of disciplines and pursuits to visit campus. Carefully organized field trips, special events, and a film series also contribute to the comprehensive educational atmosphere in which scholars are challenged not only to examine, but, more importantly, to nurture their sense of learning and leadership. 


\section{Selection to the Governors Scholars Program}

In order to participate in the Program, students must be nominated by their high schools and then compete on a state-wide level. Selection for the program is highly competitive, with an application process similar to that of prestigious colleges and universities. In addition to an academic profile that includes difficulty of course load, GPA, and at least one standardized test score, the application requires an outline of all extracurricular activities, a history of volunteer service, and a list of job positions held. Teacher recommendations include both quantitative evaluation and qualitative descriptions of the student's performance and potential. The final component of the application is an original essay.

\section{Engineering curriculum at the Governors Scholars Program}

The Governor's Scholars Program is one that doesn't just teach students classroom lessons. It is a program that breeds excellence and takes the raw fiber of a student's good work ethic and intelligence and weaves it into something greater and much more profound. The Scholars of today are most definitely the leaders of tomorrow, in whatever we may choose to do with our life. The Program is somewhat "nontraditional". Focus is on "opening the mind," not just providing facts. Minds are stretched and expanded. Faculty develops their own curriculum and course content based on the overall structure that GSP is built on. If there are more than one sections of the of focus area, the area of concentration might also be different based on the instructor. According to the National Academy of Engineering (NAE) "Only 40-60 percent of entering engineering students persist to an engineering degree, and women and minorities are at the low end of that range. These retention rates represent an unacceptable systemic failure to support student learning in the field." An early identification of the sought career would help the students retain while they go through the engineering school.

In this paper, the author describes the curriculum only for the engineering focus area and especially looking at the manufacturing engineering field. As said earlier, the duration for the governor's scholar program is five weeks. Author introduces manufacturing engineering and various aspects and tools of manufacturing engineering into the engineering focus area of the Governors Scholars Program. The intention of the engineering focus (related to manufacturing) is to provide the knowledge and skill set the student needs to in order to succeed in a creditbearing course in a post secondary institution, it's also a medium to provide the students with the proficiency of manufacturing and related engineering to see if it is that of interest for students when they pick their career.

Manufacturing engineering is a discipline of engineering that deals with the practices and research and development (design and manufacturing) of systems, manufacturing process, the design and selection of machines and tools to get the desired output (product). Manufacturing engineering also looks at the complete product life cycle of the product or system designed. The curriculum is best delivered through partnership working. All stake holders (scholars, faculty, speakers, sponsor companies and institutions) work together for a common understanding around the skills intended for the students to pick up during the five week program. Together it should be able to deliver the experience to make the decisions. All the field trips are sponsored through the sponsoring companies. 


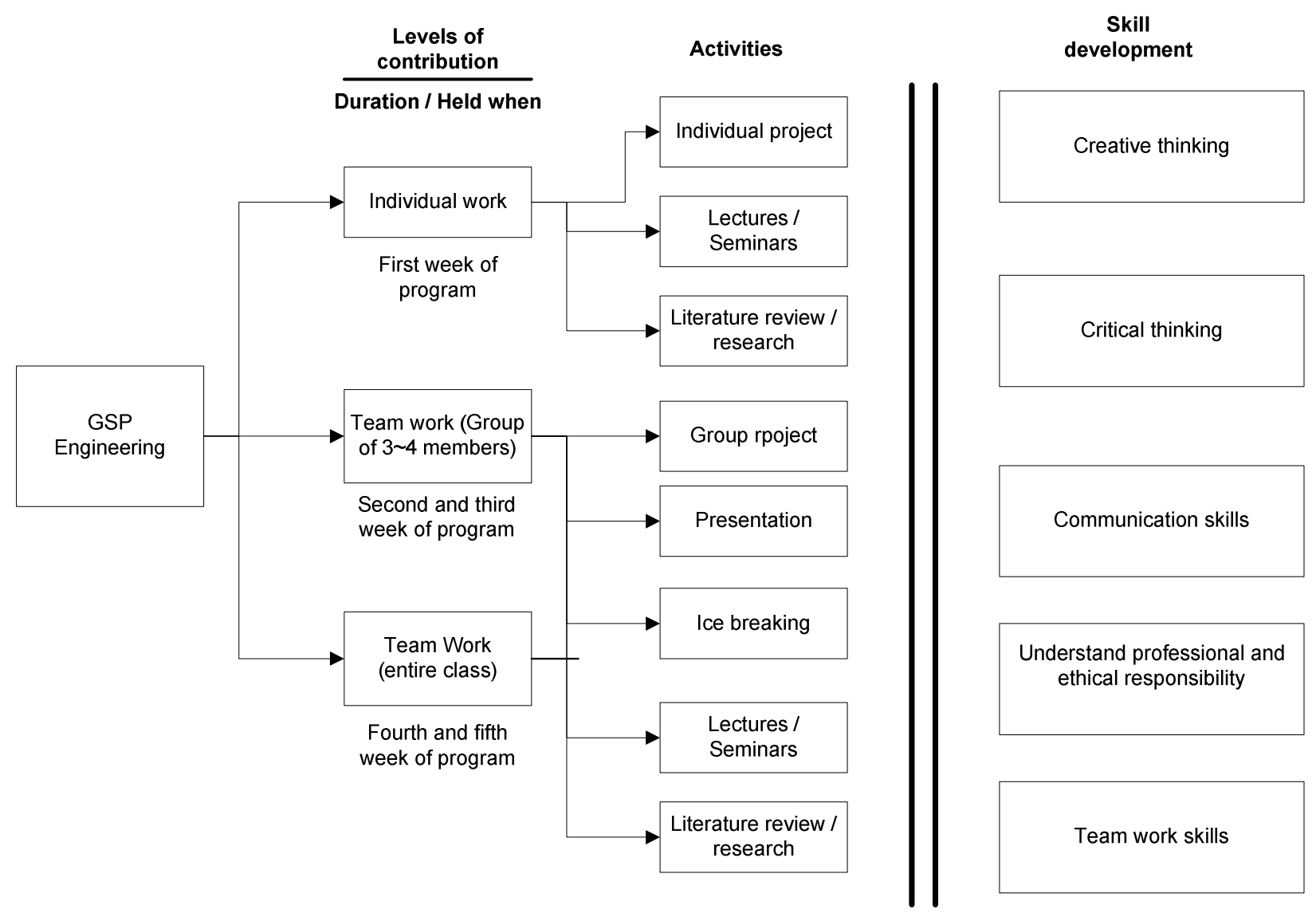

Figure 1: Activities at engineering focus area

\section{General format of classes}

The contents of the program would be explained in a weekly basis on the topics that are covered weekly.

Typically every week would contain the following activities

- Lecture

- Activity oriented field trip

- Research

- Project work

- Seminar

\section{Progression of the class and introduction of the various manufacturing engineering topics}

The scholars at the Governors Scholars Program are from different counties of the state, the scholars will get to know their peers only during the first couple week of classes. The idea behind the structure is to slowly introduce them through individual work and with ice breaking 
sessions. Figure 1: shows the different activities that are involved in the engineering focus curriculum.

The class initiated with the discussion about "what engineering is" and the different majors in engineering and how the various majors would help in improving our nation. After their exploration on engineering, the class was given a lecture on the five-stage engineering design process that is used in designing products and systems. The five engineering design stages includes defining the problem, gathering information, generating alternative solutions, analyzing solutions, and finally testing and implementing solution. All the skills that were listed earlier were discussed within the design process cycle and discussion followed on how these skills are incorporated in the design cycle for a successful project. For example under gathering information stage students brainstormed for ideas and also researched in journals for the relevant topics in their project. The design stages were discussed in detail and students also learnt the basic concept of technical drawing \& standards and its importance in the modern era.

Finally they get to do research on manufacturing engineering. A small individual project is given at the end of the research, based on the client letter they find out the objectives and constraints for the project and they come up with the design and construct the same. The individual project is usually designing a puzzle. The individual project that was assigned to scholars was to design a puzzle cube with twenty-seven mini cubes. The scholars were given an objective and numerous constraints, based on the objectives and constraints scholars had to come up with three conceptual designs by sketching. A close analysis was then done to select the final design. After finalizing the design scholars created the prototype of the selected design. The puzzle cubes that was designed and created were then used as a real time example to explain the statistical concepts in engineering. Normal distribution, six sigma, error reduction, and quality concepts were discussed based on the activity. Lecture on CAD solid models are done and student get to use solid works for their project work, at this point of time students gets introduced to Computer Aided Design (CAD) and other skills that are required for product design. The concept of product life cycle manufacturing is also introduced. Students discuss the entire life cycle of the product right from the conception through design, manufacture, and to the end of life. Students also discuss the different concepts like the "cradle to grave" and "cradle to cradle" concepts. The topics related to system management are also discussed.

Based on the final design of the puzzle it gets tested to the peers in the class. Students record the observation on how quickly their peers are able to solve the puzzle. The concepts of Operations Research (OR) is introduced at the this point of time. Based on the complexity of the puzzle scholars try to identify the age group that the puzzle would fit. They do a research and try to explain with the facts the best fit for the puzzle, this point of time they get introduced to ergonomics.

Week 2 3 
After going through the concepts, students were engaged in an individual project then with a team project of three scholars and finally a group class project. Later a class discussion followed on team effectiveness. The scholars then came up with a list for and being an effective team member and also the methods to improve team effectiveness. From the second week onwards, the students start to work in groups. The scholars are assigned a group project and they work in a group of three to four. The project is selected in the area of hydraulic or pneumatic mechanisms. Students design a hydraulic arm based on the hydraulics / pneumatic mechanism. Initially concept is visualized using CAD software and a working prototype is built. The scholars at this point understand the various concepts of team formation. Scholars understand the various stages of team formation forming, storming, forming, and performing. Since is the first time that the scholars get to start working in teams, they will exactly understand how the various stages team formation occurs. The role of the instructor is to use the stages of team development as a guide and facilitate the team's natural progression through them. Figure 2 shows the various stages in the contribution of students.

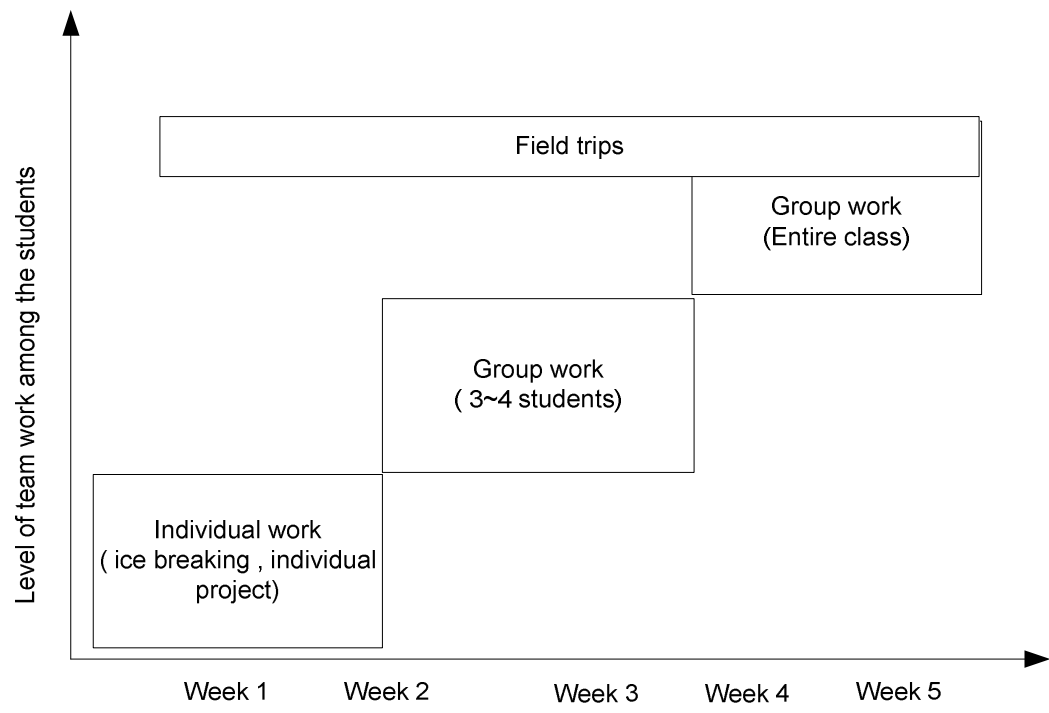

Figure 2: Level of contribution

\section{Week 4 5}

In the final couple of weeks, the entire class is assigned a project. Students are given a system to design and they make the initiative to spit themselves into individual teams to develop the part of the system. At the end of the fifth week they demonstrate the working system. It involves a lot of 
team work and project management components and they understand the need to work in team and appreciate the peer work. Table 1 which is shown in the appendix provides the step by step information regarding what happens every week at GSP.

Field Trips / real time experience

During the five week of the program scholars undertook various field trip which includes Toyota George town, Lexmark, Eastern Kentucky power, and with US corps. All these field trip includes a facility tour with student projects and presentation involved. For example at the Toyota field trip, the students take a tour of the Toyota Camry plant, during the tour they stop in one of the manufacturing cells, the wind shield wiper installation cell and they get a closer look at the process. At the end of the tour and they are briefed with a scenario and students will have to solve the problem and provide suggestion for improvement. In order to solve the problem students are provided with a data set spanning for the last one year. Students get introduced to different process improvement tools like fish bone diagram, and various other quality control charts. Students get about 6 hours to work on the problem and at the end of the day they will have to present their finding to upper management at Toyota. This is the type of commitment that stake holder have towards the program.

\section{Conclusion}

Thirty years have passed since the inception of the Governors Scholars Program and it have proven to be both popular and a very effective program in terms of delivery and acceptance to the future citizens. The GSP had been a stimulating program for outstanding high school juniors from across the Commonwealth, it has served to enlighten and inspire the scholars as well as provide them academic and personal growth in a challenging environment that balances a strong liberal arts program with a full co-curricular and residential life experience. The engineering focus area introducing them to manufacturing arena has found to be successful based on the feedback evaluations that were received from the students.

References

1. "Welcome to Kentucky Governor's Scholars Program.", www.ky.gsp.gov, Kentucky Governor's Scholars Program Home. Kentucky Governor's Scholars Program. 1024 Capital Center Drive, Suite 210, Frankfort, KY 40601, n.d. Web. Nov.-Dec. 2012.

2. Hawat, G., Regis, H., Valencia Community College, “Pre-Engineering Programs: A Seamless Approach to Connecting K-12 to the University"

3. Mohammed, R., Ganiyu, A., Hampton University, "Six Year Study of Pre-Engineering Program at the Hampton University"

4. National Academy of Engineering (NAE), 2005. Educating the Engineer of 2020: Adapting Engineering Education to the New Century, Washington, DC: The National Academy Press.

5. Besterfield-Sacre, M., C.J. Atman, and L.J. Shuman, 1997. Characteristics of Freshman Engineering Students: Models for Determining Student Attrition in Engineering. Journal of Engineering Education, 86: 139-149. 


\begin{tabular}{|c|c|c|c|c|c|c|}
\hline \multicolumn{7}{|c|}{ Appendix } \\
\hline & Week 1 & \multicolumn{2}{|l|}{ Week 2} & Week 3 & Week 4 & Week 5 \\
\hline Lecture & $\begin{array}{ll}\text { - Introduction to CAD } \\
\text { Engineering design } \\
\text { process } \\
\text { Introducing to client } \\
\text { letter, objectives, } \\
\text { constraints, functions, } \\
\text { conceptual design }\end{array}$ & \multicolumn{2}{|c|}{$\begin{array}{l}\text { Introduction to } \\
\text { PLCM (product life } \\
\text { cycle management) } \\
\text { - Introduction to } \\
\text { sustainability }\end{array}$} & $\begin{array}{l}\text { Hydraulics and } \\
\text { pneumatics }\end{array}$ & Energy generation & $\begin{array}{l}\text { System integration } \\
\text { and } \\
\text { implementation }\end{array}$ \\
\hline Project & $\begin{array}{l}\text { Design a cube based on } \\
\text { client letter }\end{array}$ & \multicolumn{3}{|c|}{ Designing an hydraulic arm } & \multicolumn{2}{|c|}{$\begin{array}{l}\text { Designing a system that involves energy } \\
\text { conversion and hydraulics arm } \\
\text { mechanisms }\end{array}$} \\
\hline $\begin{array}{l}\text { Activities for } \\
\text { the project }\end{array}$ & $\begin{array}{l}\text { - } \text { CAD work } \\
\text { - } \text { Research } \\
\text { - } \text { Identifying client } \\
\text { requirements, } \\
\text { objectives, functions, } \\
\text { constraints, developing } \\
\text { conceptual design } \\
\text { - } \text { Presentation }\end{array}$ & \multicolumn{3}{|l|}{$\begin{array}{l}\text { - } \text { Ice breaking } \\
\text { - CAD work } \\
\text { - } \text { Research } \\
\text { - }\end{array}$} & \multicolumn{2}{|c|}{$\begin{array}{ll}\text { - } & \text { CAD work } \\
\text { - } & \text { Research }\end{array}$} \\
\hline Field Trip & US Corps & $\begin{array}{l}\text { Toyota } \\
\text { (George town) }\end{array}$ & \multicolumn{2}{|c|}{ Lexmark International } & $\begin{array}{l}\text { Eastern Kentucky } \\
\text { power }\end{array}$ & \\
\hline $\begin{array}{l}\text { Seminar - } \\
\text { "Introducing } \\
\text { engineering } \\
\text { majors" }\end{array}$ & $\begin{array}{l}\text { Kentucky Society of } \\
\text { Professional Engineers } \\
\text { (KSPE) }\end{array}$ & $\begin{array}{l}\text { Future } \\
\text { challenges in } \\
\text { engineering }\end{array}$ & \multicolumn{2}{|c|}{$\begin{array}{l}\text { Presentation from a major } \\
\text { engineering school }\end{array}$} & $\begin{array}{l}\text { Panel discussion on } \\
\text { engineering careers }\end{array}$ & $\begin{array}{l}\text { Presentation from a } \\
\text { major engineering } \\
\text { school }\end{array}$ \\
\hline
\end{tabular}

Table 1: Entire schedule at Governors Scholars Program (for engineering focus area) 